\title{
HOW DOES TARGETED GRASSING OF ARABLE LAND INFLUENCE DRAINAGE WATER QUALITY AND FARM ECONOMIC INDICATORS?
}

\author{
ANTONÍN ZAJÍČEK, PETR FUČÍK, RENATA DUFFKOVÁ \& JANA MAXOVÁ \\ Research Institute for Soil and Water Conservation, Prague, Czech Republic.
}

\begin{abstract}
A 7-year experiment with grassing of arable land in the catchment recharge zone was conducted in a small (60 ha) agricultural tile-drained catchment (Bohemian - Moravian Highlands, Czech Republic). Together with water quality, the effect of increasing grassland area on selected farm economic indicators was evaluated. The area for grassing was delimitated by the method of relative soil infiltration vulnerability based on the analysis of five-digit valuated soil ecological unit code, available as shp file at the scale 1:5000. Effect of grassing on farm budget was estimated by comparison of revenues (crop sales and subsidies) with technology costs of three different grassland area proportion within the agricultural land managed by the farm ( $1200 \mathrm{ha}$ ). It was proved that nitrate concentrations in drainage water were influenced predominantly by the land use of the recharge zones within the drainage subcatchment. The grassing of arable land focused into proper catchment area (recharge zone) demonstrated a significant decrease in both $\mathrm{NO}_{3}$ concentrations and $\mathrm{N}$ loads by $35 \%$ and $25 \%$, respectively. On the other hand, increasing areas of grasslands would lead to decrease of landscape productive service, farm turnover and profit and the bigger dependence on subsidies. That's why it is necessary to consider the non-productive functions of grasslands also as public service, taking into account the savings in water cleaning costs and the price of increased water retention. Presented approach come forward when setting the subsidies dealing with soil and water protective measures in agrarian landscape.

Keywords: nitrate concentration subsidies, recharge area, targeted grassing, technological costs, tile drainage
\end{abstract}

\section{INTRODUCTION}

Nitrates represent one of the main products of non-point water pollution, particularly in association with a high extent of agricultural land [1]. Nitrates enter surface water mainly by subsurface runoff, which is often represented by water from agricultural drainage. In small agricultural catchments in area of the Bohemian-Moravian Highlands crystallinum, the proportion of stream flow and nutrient load coming from tile drainage outlets was estimated to be $65-75 \%$ [2]. Drainage systems in this area are characterized by their locations in slopes, in transient zones, or at interfaces of transient and discharge zones [3]. In such cases, the entire catchment must be taken into account for water balance studies, since a considerable proportion of the drainage runoff can originate outside the drained area $[4,5]$. These areas, called recharge or source areas, situated in the upper parts of slopes with shallow, highly permeable soil may represent, in intensively managed agricultural land, a significant source of leaching nutrients $(\mathrm{N}, \mathrm{P})$ and other pollutants (pesticides), especially when these localities are connected to drainage systems capturing both springs and shallow subsurface flow.

Grassing of arable land belongs to the preventive nitrogen remedial measures aimed at reducing nitrogen leaching from the soil. This important non-productive function of grassland is induced mainly by the fact that grassland can absorb and use bigger amount of nitrogen in comparison to field crops and this ability remains for longer period within the year. Permanent grasslands (PGs) cover the soil year round and employ large active subsurface biomass in the root system, which can utilize a significant amount of soil nitrogen. Moreover, grassland increases activity of soil microbes, which is much higher than under field crops. 
This contributes to the retention of nitrates in the soil by their immobilization [6]. The regulatory ecosystem function of PG allows fertilization with high nitrogen doses without negative impacts on water quality (up to $200 \mathrm{~kg} / \mathrm{ha} /$ year [7]). Besides nitrogen remedial ability, grasslands have also other supporting and regulatory functions such as carbon sequestration, reduction of soil erosion, increase of water retention in the landscape, and optionally reduction of pesticide leaching $[8,9]$. On the other hand, the excessive conversion of arable land to grassland has also negative aspects, such as decrease in provisioning ecosystem services, namely reduction in the area for cultivation of commercial field crops [10].

Main goal of this article was to evaluate the effect of grassing on both the quality of drainage water and also on the selected economic indicators of a farming company (agricultural cooperative).

\section{MATERIALS AND METHODS}

The grassing experiment was conducted in small agricultural catchment, Dehtáre (Fig. 1), situated in the Bohemian-Moravian Highlands, Czech Republic. It is a locally typical small agricultural catchment, where the tile drainage acts as the only permanent runoff from the catchment and the drainage system was built in the slope. Its area is 58 ha, with tile-drained areas occupying 19 ha (32\% of the catchment). It is used mainly as agricultural land, with low forest representation. The agricultural land is mostly exploited as arable, with PG in the lower part of the catchment. The altitude varies between 550 and $497 \mathrm{~m}$ asl. Average year precipitation is $666 \mathrm{~mm}$. The representation of soils (according to the World Reference Base for Soil Resources 2006) is variable, with Gleyed Cambisols, Gleysols and sporadically Histosols. In the recharge area, the soil cover is more homogenous, with prevailing Modal, Ranker and Arenic Cambisols. More detailed catchment description is given, e.g. in [11]. The experiment itself consisted in delimitation of the source area using the method defined by Janglova et al. [12]. This method is based on the analysis of soil conditions characterized by five-digit code of valuated soil ecological units (VSEU). The VSEU code characterizes main soil units, slope, exposure, skeletal character and soil depth. Based on the categorization of these criteria, soil is classified into five relative groups according to its significance for the infiltration process, with category 1 corresponding to the maximum infiltration capacity. Part of catchment recharge area defined by this method (4.6 ha) was grassed in 2006. During further routine management, we monitored changes in nitrate concentrations in drainage water at several drainage subsystems located in places with differing land use in the source (upper slope parts near the drainage divide) and outlet (lower slope parts) areas. To evaluate the effects of grassing, the whole monitored time was divided into two periods, period 1 - before grassing (2003-2006) and period 2 - after grassing (2007-2013). All grasslands in the catchment were fertilized by approximately $100 \mathrm{~kg} \mathrm{~N} / \mathrm{ha}$ per season (mostly by urea and pig slurry digestate). The arable land in the catchment was fertilized according to crop rotation (cereals, potatoes and oilseed rape) in the amount of ca. 120-170 kg N/ha per season.

There were four monitored sites on drainage system in experimental field with different land use recharge and discharge zones of their subcatchments (Fig. 1). Site K1 (PG in the outlet area, grassing of the recharge area in period 2), K5 (arable land in the entire subcatchment during the entire experiment) and K4 (PG in the outlet area and arable land in the recharge area during the entire experiment). Drainage water from all these drainage subsystems was monitored in site KL, which is the closing profile of the entire drainage group. The experimental methodology was described in detail by $[13,14]$.

The economic evaluation of arable land grassing included calculation of technological costs for cultivation of particular crops according to the typical crop rotation in studied region, and their comparison with the income composed of the value of the particular crop production 


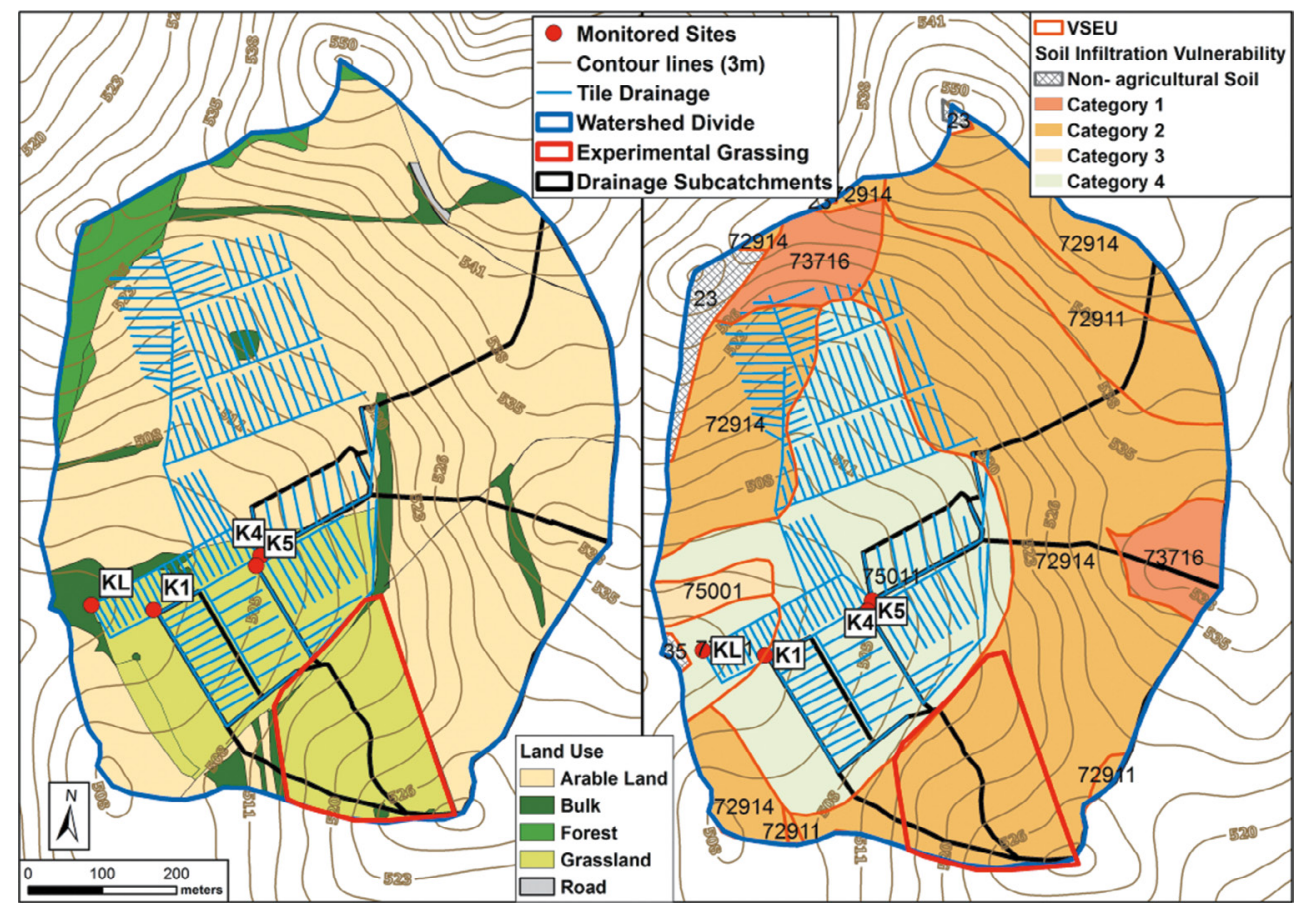

Figure 1: An overview map of the Dehtáře experimental catchment.

and the level of subsidies allocated to the field with this crop. The costs and income were both estimated for the year 2015. The data obtained from the Czech Statistical Office [15], various agricultural norms [16] and the level of subsidies were derived from the State Agricultural Intervention Fund and the Ministry of Agriculture of the Czech Republic [17]. These data were also consulted with farmers operating in the studied locality and its close neighbourhood. The costs and income were related to 1 ha and year and then to the 7-year crop rotation, which is mostly used in the studied locality (clover, winter wheat, spring barley/corn, winter oil seed rape, winter wheat, potatoes/corn, spring barley with clover undersowing). Evaluation of the experiment itself was done for 1 year and the area of 4.6 ha (the extent of grassing). The increase in the proportion of grassing was evaluated for three different variants of arable land/grassland proportions for a hypothetical farm with a typical size of agricultural land in the region. Variant A, considered as initial state, represents 1,500 ha of arable land and 300 ha of PG; variant B represents doubling of PG area at the expense of arable land, i.e., 1,200 ha of arable land and 600 ha of PG; and variant $C$ represents equal shares of arable land and PG, i.e., 900 ha of arable land and 900 ha of PG. All incomes and costs are expressed in Czech Crows (CZK). The average exchange rate is $27 \mathrm{CZK}$ for $1 \mathrm{EURO}$.

\section{RESULTS}

\subsection{The effect of grassing on the drainage water quality}

The nitrate concentrations in drainage waters were strongly variable during season (dependence on the discharge levels) and also in comparison of particular seasons (different precipitation course in particular season and by crops rotation). The measured $\mathrm{NO}_{3}$ 


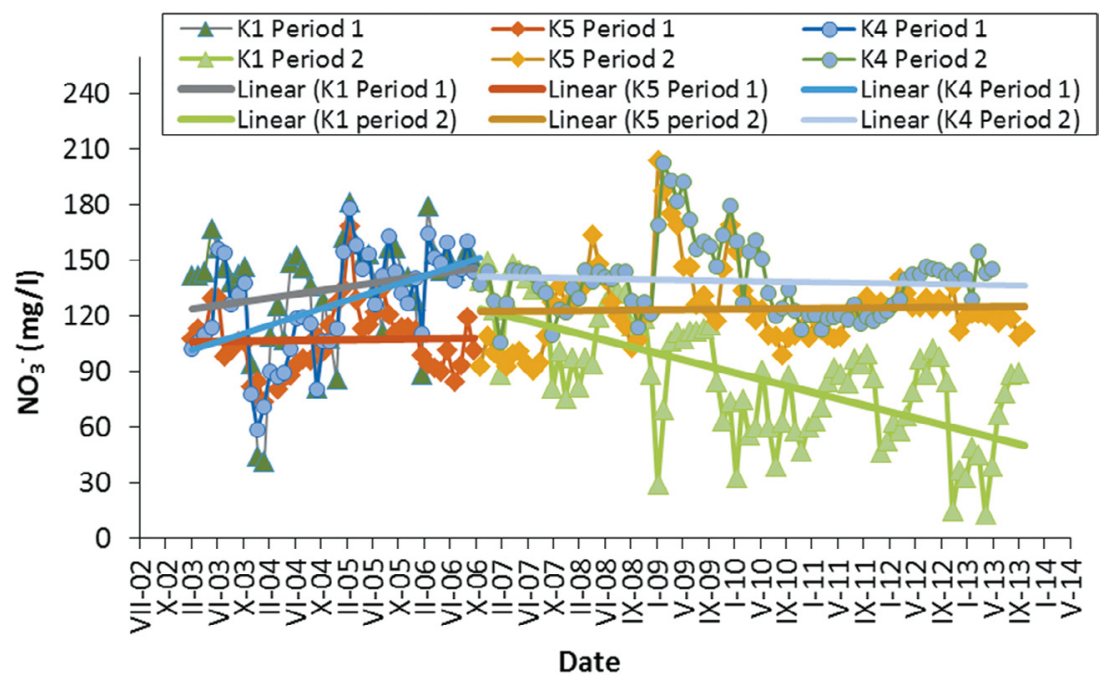

Figure 2: The long-term trend of nitrate concentrations in the drainage subsystems with different land use within the experiment. Site K1 had grassed recharge zone in period 2 .

concentrations varied from 18 to $253 \mathrm{mg} / \mathrm{l}$; the monthly flow-weighted concentrations (Cfw) varied from 13 to $197 \mathrm{mg} / \mathrm{l}$. In period 1 (before grassing the recharge zone), $\mathrm{Cfw}$ values were surprisingly higher in sites $\mathrm{K} 1$, and $\mathrm{K} 4$ with the PG in drained area (discharge zone) than in site under arable land (K5) (Fig. 2). After grassing the K1 subsystem recharge area, some changes occurred. Approximately 1 year after grassing, the long-term course of $\mathrm{NO}_{3}$ concentrations changed direction and became decreasing in the site with grassed recharge zone. In sites without land-use change (K5, K4), the nitrate Cfw trend remained increasing or the stagnation was found. Results of Kruskal-Wallis test, which evaluated the significance of nitrate concentration change, showed a statistically significant decrease happened in sites with the grassed recharge area. Further analysis of nitrate concentrations during both monitored periods (Fig. 3) showed the clearly demonstrable decrease by $26-32 \%$ at drainage subsystem $\mathrm{K} 1$, whose recharge area was completely grassed. The fall in concentrations was observed despite the fact that fertilization of the PG continued. The box plots (Fig. 3) also show increase of nitrate concentrations at drainage subsystem K5 with arable land in both discharge and recharge areas, and stagnation (or mild increase) of these concentrations at drainage subsystem K4 with PG in the discharge area and arable land in the recharge area. The entire drainage group KL (20\% of recharge area grassed) showed a decrease in nitrate concentrations by $11 \%$. Along with the decreased nitrate concentrations, there was also detected a drop in nitrogen load by $23 \%$ (from $38.4 \mathrm{~kg} / \mathrm{ha} / \mathrm{year}$ to $31.2 \mathrm{~kg} / \mathrm{ha} /$ year) from the whole KL drainage group subcatchment whose source area was partly grassed, and by $47 \%$ (from $57.0 \mathrm{~kg} / \mathrm{ha} /$ year to $39.6 \mathrm{~kg} / \mathrm{ha} /$ year) at drainage subsystem K1 whose source area was grassed completely. In the same period, the drainage subsystem K5, where no change in land use occurred (arable land), displayed increase in nitrogen loss by $17 \%$. 


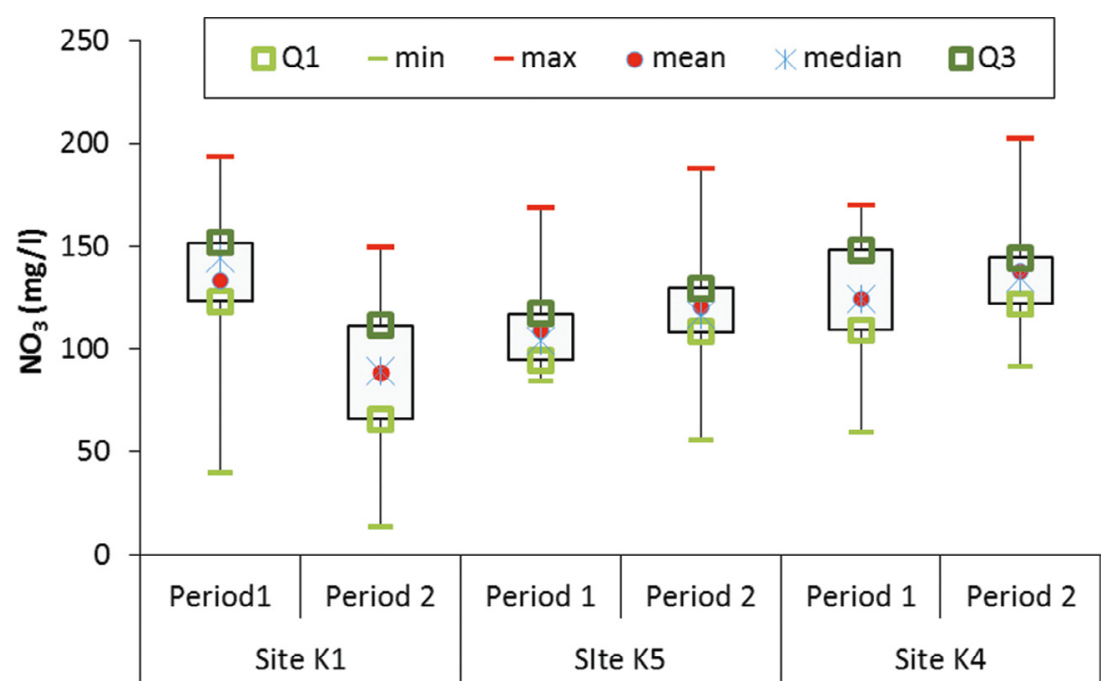

Figure 3: Nitrate concentrations in drainage waters of subsystem K1 (grasssed recharge zone in period 2), subsystem K5 (arable land in the whole area), and subsystem $\mathrm{K} 4$ (grassland in discharge zone, arable land in recharge area).

\subsection{Financial assessment of grassing}

The income from the main crops according to the crop rotation in the pilot area is shown in Table 1. The income value comprises the value of products from plant production and the value of subsidies per hectare of agricultural area depending on the particular crop. The highest income from the main crops was generated by potatoes, followed by oilseed rape and wheat; in contrast, the income from clover and grassland was the lowest. A significant part of the plant production income is currently represented by the subsidies. The subsidies level in 2015 for the majority of crops cultivated on arable land of the pilot locality was about 5 $400 \mathrm{CZK} / \mathrm{ha}$ (SAPS - direct payment per 1 ha and Greening). This amount referred to clover, potatoes, maize, wheat and oilseed rape. The subsidies for potato cultivation was increased in 2015 by 'voluntary coupled support', and the total support for ware potatoes thus reached $18,605 \mathrm{CZK} / \mathrm{ha}$ in the pilot area. In the case of PG, total level of subsidies in the studied locality may reach approximately 10,300 CZK/ha (LFA and AEKO, amounting to approximately 1,240 and 2,592 CZK/ha, respectively). The proportion of subsidies in the income per hectare represents $75.5 \%$ for PG and an in an average of $17.2 \%$ for arable land.

Technological costs for the main assessed crops are given in Table 2. Again, the highest costs were associated with ware potatoes; the second position, far behind, was held by oilseed rape. The technological costs for cereals were similar. Logically, the lowest costs were associated with PG, where in most cases there are additional savings on seeds and chemicals in the following years. However, the relatively high costs (with regard to the income) of tractor work still remain.

The results of a simple analysis of income and costs of plant production for a 7-year crop rotation with differing ratio of arable land and PG are given in Table 3. The decrease in both 
income and technological costs for both assessed variants $(\mathrm{B}, \mathrm{C})$ displays a parallel slope. In case of doubling the PG share (variant B), the income decreased by $12.5 \%$ and the technological costs by $13.5 \%$. In case of equal shares of arable land and PG (variant C; 900 ha of arable land and 900 ha of PG), the income decreased by $25.0 \%$ and technological costs by $26.7 \%$ compared to the initial situation. The difference between the income and the technological costs decreased slightly slower; in the case of 600 ha of PG (variant B) it dropped by $9.5 \%$ and in the case of equal share of arable land and PG (variant C) by $18.8 \%$. This was caused by the higher proportion of subsidies for grassing included into the income, which in the studied variants grew from the initial $21.2 \%$ to $26.9 \%$ in the case of 1200 ha of arable land/900 ha of PG and to $32.1 \%$ in the case of equal share of arable land and PG.

Table 1: Incomes from crop production (main product value and subsidies level).

\begin{tabular}{lcccc}
\hline \multicolumn{5}{c}{ Income from Crop Production by 1 year and 1 ha } \\
\hline Crop & $\begin{array}{c}\text { Crop Value } \\
\text { (Thousands } \\
\text { of CZK/ha) }\end{array}$ & $\begin{array}{c}\text { Subsidies } \\
\text { (Thousands } \\
\text { of CZK/ha) }\end{array}$ & $\begin{array}{c}\text { Income } \\
\text { (Thousands } \\
\text { of CZK/ha) }\end{array}$ & $\begin{array}{c}\text { Subsidies } \\
\text { Share (\%) }\end{array}$ \\
\hline Grassland & 3.4 & 10.3 & 13.7 & 75.5 \\
Clover & 13.7 & 5.4 & 19.1 & 28.3 \\
Winter wheat & 28.6 & 5.4 & 34.0 & 15.9 \\
Spring barley & 18.7 & 5.4 & 24.1 & 22.5 \\
Oilseed rape & 39.5 & 5.4 & 44.9 & 12.0 \\
Potatoes & 84.0 & 17.8 & 101.8 & 17.5 \\
Silage maize & 27.3 & 5.4 & 32.7 & 16.5 \\
\hline \multicolumn{5}{c}{ Income from 7 year crop rotation and 4.6 ha experimental area } \\
\hline Crop rotation & $1,105.6$ & 230.9 & $1,336.5$ & 17.3 \\
Grassland & 107.9 & 331.7 & 439.5 & 75.5 \\
\hline
\end{tabular}

Table 2: Technological costs for growing main crops in region in interest.

\begin{tabular}{lcccccccc}
\hline \multicolumn{7}{c}{ Technological Costs for Agricultural Production by 1 Year and 1 ha (thousands of CZK) } \\
\hline Crop & Fuel & Work & Machinery & Seeds & Fertilizers & Chems. & Fixed & Total \\
\hline Grassland & 0.9 & 0.5 & 4.0 & 0.6 & 0.3 & 0.0 & 3.0 & 9.3 \\
Clover & 1.9 & 0.8 & 6.0 & 2.3 & 0.0 & 0.5 & 4.0 & 15.4 \\
Winter wheat & 1.8 & 0.8 & 4.7 & 2.2 & 5.3 & 4.0 & 4.8 & 23.7 \\
Spring barley & 1.9 & 0.6 & 4.3 & 2.0 & 6.4 & 1.5 & 5.0 & 21.6 \\
Oil seed rape & 1.9 & 0.8 & 4.3 & 2.0 & 10.5 & 6.0 & 4.6 & 30.1 \\
Potatoes & 3.9 & 4.0 & 17.6 & 21.1 & 5.2 & 8.9 & 20.0 & 80.7 \\
Silage maize & 3.0 & 1.0 & 6.5 & 2.0 & 5.8 & 1.4 & 7.3 & 27.0 \\
\hline \multicolumn{7}{c}{ Technological Costs for Agricultural Production by 7 year Crop Rotation and 4.6 ha } \\
Crop rotation & 74.4 & 40.6 & 220.8 & 155.8 & 177.2 & 121.3 & 232.1 & $1,021.9$ \\
Grassland & 29.0 & 14.8 & 128.9 & 0.6 & 9.7 & 0.0 & 96.6 & 299.1 \\
\hline
\end{tabular}


Table 3: Comparison of Costs and Incomes of an agricultural company with changing proportion of grasslands and arable land.

\begin{tabular}{lcccc}
\hline \multicolumn{1}{c}{ Variant } & $\begin{array}{l}\text { Incomes } \\
\text { (Millions of } \\
\text { CZK) }\end{array}$ & $\begin{array}{l}\text { Subsidies } \\
\text { Share (\%) }\end{array}$ & $\begin{array}{l}\text { Technological Costs } \\
\text { (Millions of CZK) }\end{array}$ & $\begin{array}{l}\text { Difference } \\
\text { (Millions of } \\
\text { CZK) }\end{array}$ \\
\hline $\begin{array}{l}\text { A (1,500 ha } \\
\text { arable/300 ha PG) }\end{array}$ & 456,4 & 21,2 & 352,7 & 103,7 \\
$\begin{array}{l}\text { B (1,200 ha } \\
\text { arable/600 ha PG) }\end{array}$ & 399,5 & 25,9 & 305,6 & 93,9 \\
$\begin{array}{l}\text { C (900 ha } \\
\text { arable/900 ha PG) }\end{array}$ & 342,6 & 32,1 & 258,5 & 84,2 \\
\hline
\end{tabular}

\section{DISCUSSION}

The above-mentioned results provide evidence for the positive effect of grassing on the drainage water quality. While PG situated in the outlet area directly above the drainage system (in the lowest part of the drained catchment) played no role in the nitrate concentrations in the drainage water, grassing of source areas resulted in their permanent, statistically significant reduction. To ensure effectiveness of grassing as an approach for reducing the nitrogen burden of water, it has to be applied to appropriately delimitated source (vulnerable) areas with shallowest soil, where most of the runoff from the catchment originates. For this, a number of certified methodologies developed by Research Institute for Soil and Water Conservation can be employed. Grassing is also advantageous by the possibility to use liquid manure, whose application to the grass cover is not associated with the risk of increased nitrate leaching [18].

With regard to economy, the increase in grassed areas undoubtedly results in reduction of farm turnover. As well, the drop in the costs and income will lead to reduction of the profit, which will be partly compensated for by higher PG support. Higher dependence on the support, however, is disputable in view of the long-term stability of a farm because the amount and focus of the support may change year after year. It should also be noted that the production value of PG and clover, and partly of corn as well, is relevant only when the agricultural subject also maintains animal production, or optionally a biogas station, while considering the amount of grass mass that the agricultural subject is able to process.

Besides the positive effect on water quality and extra-productive landscape function, grassing of arable land can also be perceived as a public service that will increase the value of other landscape ecosystem functions, such as regulatory and aesthetic functions. Monetary evaluation of these ecosystem services is only meaningful when grassing is actually perceived as a public service. It means not only the increase of ecosystem landscape functions and improvement of water retention in agricultural soil, namely in cases of intensive rainfallrunoff events, but also saving of the costs of removal of nitrates (and also of pesticides) from water in water processing plants. The reported value of $1 \mathrm{~m}^{3}$ water retention in the landscape represents approximately CZK 500 per year [9]. The estimated costs of water processing plants (regeneration salt and elimination of wastewater) for decreasing the nitrate concentrations from $50 \mathrm{mg} / \mathrm{l}$ to $15 \mathrm{mg} / \mathrm{l}$ range around CZK 3.2 and for decreasing the nitrate concentrations from $100 \mathrm{mg} / \mathrm{l}$ to $43 \mathrm{mg} / \mathrm{l}$ even around CZK 6.3 per $1 \mathrm{~m}^{3}$ (according to data from 
water management companies ). These data should be taken into account when determining the amount of support allocated to public service provided by farm management, aimed at improvement of landscape functions.

\section{CONLUSIONS}

The experiment proved that appropriate management of properly delimitated recharge area can improve water quality in the catchment. While PG placed directly in the drained area (catchment discharge zone) did not show any effect, the grassing focused on the catchment recharge area demonstrated a significant decrease in $\mathrm{NO}_{3}$ concentrations. Hence, the grassing focused to the proper catchment area (recharge zone) can be a useful, effective and relatively cheap measure for improvement of shallow groundwater quality, or optionally the quality of local drinking water sources.. On the other hand, increasing areas of grasslands would lead to decrease of landscape productive service, farm turnover and profit and the bigger dependence on subsidies. That's why the grassing should be applied in small, precisely defined parts of the catchment and it is necessary to consider the non-productive functions of grasslands also as public service, taking into account the saves in water cleaning costs and the price of increased water retention. Presented approach come forward when setting the subsidies dealing with soil and water protective measures in agrarian landscapes.

\section{ACKNOWLEDGEMENTS}

This article was prepared under the support of project no. 633945 FATIMA Farming Tools for external Inputs and water Management (The EU Framework Programme for Research and Innovation, Horizon 2020). Authors wish to thank the Kojčice Agricultural Cooperative for research support and data providing.

\section{REFERENCES}

[1] Fučík, P., Kvítek, T., Lexa, M., Novák, P. \& Bílková, A., Assessing the stream water quality dynamics in connection with land use in agricultural catchments of different scales. Soil and Water Research 2008(3), pp. 98-112, 2008.

[2] Doležal, F., Kulhavý, Z., Soukup, M. \& Kodešová, R., Hydrology of tile drainage Run off. Physics and Chemistry of the Earth (B), 26(7-8), pp. 623-627, 2001. DOI: 10.1016/ S1464-1909(01)00059-4.

[3] Doležal, F. \& Kvítek T., The role of recharge zones, discharge zones, springs and tile drainage systems in peneplains of Central European Highlands with regard to water quality generation processes. Physics and Chemistry of the Earth, 2004(29), pp. 775785, 2004. DOI: 10.1016/j.pce.2004.05.005

[4] Herrmann, A. \& Duncker, D., Runoff formation in a tile-drained agricultural basin of the Harz Mountain Foreland, Northern Germany. Soil and Water Research, 3(3), pp. 83-97, 2008.

[5] Zajíček, A., Kvítek, T., Kaplická, M., Doležal, F., Kulhavý, Z., Bystřický, V. \& Žlábek, P., Drainage water temperature as a basis for verifying drainage runoff composition on slopes. Hydrological Processes, 2011(25), pp. 3204-3215, 2011. DOI 10.1002/ hyp.8039.

[6] Griffiths, B.S., Hallett, P.D., Kuan, H.L., Gregory, A.S., Watts, C.W. \& Whitmore, A.P., Functional resilience of soil microbial communities depends on both soil structure and microbial community composition. Biology and Fertility of Soils, 44, pp. 745-754, 2008. DOI: 10.1007/s00374-007-0257-z. 
[7] Fiala, J., Recent management systems of grasslands - (1st part). Úroda, 6, pp. 9-11, 2002. (In Czech)

[8] Hejduk, S., Grasslands Ecosystem, Perennial Grassland as Landscape Forming Tool. MZLU: Brno, pp. 45-50, 2007. ISBN 978-80-7375-045-9. in Slovak)

[9] Hönigová, I., Vačkář, D., Lorencová, E., Melichar, J., Götzl, M., Sonderegger, G., Oušková, V., Hošek, M. \& Chobot, K., Survey on grassland ecosystem services - Report of the European Topic Centre on Biological Diversity. Nature conservation agency of the Czech Republic, 78 p., 2012.

[10] Hauck, J., Schleyer, CH., Winkler, K. J. \& Maes, J., Shades of greening: reviewing the impact of the new EU agricultural policy on ecosystem services. Change Adaptation Socioecological Systems, 1, pp. 51-62, 2014. DOI: 10.2478/cass-2014-0006

[11] Nováková, E., Karous, M., Zajíček, A. \& Karousová, M., Evaluation of ground penetrating radar and vertical electrical sounding methods to determine soil horizons and bedrock at the locality Dehtáre. Soil and Water Research, 8(3), pp. 105-112, 2013.

[12] Janglová, R., Kvítek, T. \& Novák, P., Categorisation of soil infiltration capacity based on GIS proceeding of soil survey data (In Czech). Soil and Water Scientific Studies, 2, pp. 61-81, 2003.

[13] Zajíček, A. \& Kvítek, T., The effect of grassland focused into recharge areas on nitrate concentration in drainage waters. Sovak, 22(9), pp. 14-17, 2013. (in Czech)

[14] Fučík, P., Zajíček, A., Duffková, R. \& Kvítek, T., Chapter 11: Water quality of agricultural drainage systems in the Czech Republic - Options for its improvement. Research and Practices in Water Quality, ed. T.S. Lee, InTech: Rijeka, pp. 241-262, 2015. DOI: $10.5772 / 59298$.

[15] Czech statistical office (ČSÚ), www.czso.cz

[16] Normatives for crop and food production (AGC), available at www.agronormativy.cz (in Czech)

[17] eAGRI Czech ministry of Agriculture (MZe), available at http://eagri.cz

[18] Duffková, R. \& Zajíček, A., Evaluation of groundwater quality after mulching and using slurry on grassland. Vodní hospodářství, 61(7), pp. 290-293, 2011. (in Czech) 